\title{
PENERAPAN PBL UNTUK MENINGKATKAN KEMAMPUAN PEMECAHAN MASALAH MATEMATIS SISWA KELAS X TKR 1 SMK MUHAMMADIYAH 1 PEKANBARU
}

\author{
Tia Andesma, Rini Dian Anggraini \\ Pendidikan Matematika, Universitas Riau \\ Email : tiaandesma07@gmail.com
}

\begin{abstract}
This study aimed to improve the learning process and the student's mathematical problem solving skill by applying Problem Based Learning (PBL)l. This type of study is classroom action research with two cycles. This study was conducted in collaboration between researcher and teacher of mathematics. Subjects were students of class X TKR 1 SMK Muhammadiyah 1 Pekanbaru. The study was conducted in the second semester of academic year 2018/2019. The research instrument consists of mathematical learning instruments and instruments to collect data. Mathematical learning instruments are syllabus, lesson plans, and students' worksheets. Data collection instruments are observation sheets and mathematical problem solving tests. Data analysis techniques are analysis descriptive narrative of qualitative data and descriptive statistical analysis of quantitative data. The result of this study showed that the implementation of PBL improved the learning process and the student's mathematical problem solving skill. The average of student's mathematical problem solving skill in firts cycle which is 72,09 had improved to 85,67 in second cycle. The improvement also found in the indicator average value in identifying the problem, devising a plan to solve the problem, carrying out the plan to solve the problem, and interpreting the solution. This study concludes that the implementation of PBL improved the student's mathematical problem solving skill at class X TKR I SMK Muhammadiyah 1 Pekanbaru. PBL can be used as an alternative to learning, because through this learning can improve mathematical problem solving skill of the students.
\end{abstract}

Keywords : Problem Based Learning, Mathematical problem solving skill, Learning process

\section{PENDAHULUAN}

Matematika merupakan salah satu mata pelajaran yang diajarkan di sekolah. Pembelajaran matematika yang ada di sekolah sangat erat kaitannya dengan permasalahan dalam kehidupan sehari-hari. Melalui pembelajaran matematika, siswa diharapkan mampu menyelesaikan masalah-masalah yang mengandung konsep matematika dengan kemampuan dan pengetahuan yang dimilikinya. Berdasarkan tujuan pembelajaran yang tercantum dalam Permendikbud No 58 Tahun 2014 terlihat bahwa pembelajaran matematika dapat melatih siswa untuk mengembangkan kemampuan pemahaman konsep, bernalar, mampu menyelesaikan masalah, dan mengomunikasikan gagasan serta menata cara berpikir dalam pemecahan masalah untuk menyelesaikan masalah dalam kehidupan sehari-hari.

Kemampuan pemecahan masalah matematis merupakan salah satu tujuan pembelajaran matematika yang harus memiliki oleh siswa. Menurut Polya (dalam Roebyanto dan Harmini, 2017), pemecahan masalah merupakan suatu usaha mencari jalan keluar dari suatu kesulitan guna mencapai suatu tujuan yang tidak segera dapat dicapai. Pemecahan masalah ini adalah suatu proses kompleks yang menuntut seseorang untuk mengoordinasikan pengalaman, pengetahuan, pemahaman, dan intuisi untuk menyelesaikan permasalahan yang ada. Tahapan dalam pembelajaran pemecahan masalah menurut Polya (dalam Roebyanto dan Harmini, 2017) meliputi: (1) pemahaman masalah (understanding the problem); (2) perencanaan penyelesaian (devising a plan); (3) melaksanakan perencanaan (carrying out the plan); dan (4) pemeriksaan kembali proses dan hasil (looking back). Siswa dikatakan mampu menyelesaikan atau memecahkan masalah, apabila ia telah dapat melaksanakan empat tahapan pemecahan masalah yang telah dikemukakan Polya di atas.

Berdasarkan hasil pengamatan dan wawancara di kelas $\mathrm{X}$ TKR 1 SMK Muhammadiya Pekanbaru, peneliti mengetahui bahwa pembelajaran masih berpusat pada guru dan masih berlangsung satu arah yaitu dari guru ke siswa. Siswa hanya fokus pada apa yang disampaikan oleh guru dan mencatat seluruh materi yang disampaikan oleh guru. Ketika guru memberikan kesempatan untuk 
bertanya, hanya beberapa siswa yang mau bertanya sedangkan siswa lainnya sibuk dengan kegiatan masing-masing. Dalam penyampaian materi, guru biasanya hanya memberikan rumus dan contoh soal yang bersifat rutin bukan pemecahan masalah matematis, sehingga siswa kurang dibiasakan dalam berpikir kreatif. Selain itu, guru beranggapan dengan belajar berkelompok dan berdiskusi akan membuat keributan dan membutuhkan waktu yang cukup lama sehingga mengganggu program pembelajaran yang telah dibuat. Padahal kemampuan pemecahan masalah matematis dapat berkembang apabila adanya interaksi atau bertukar pendapat dalam memecahkan soal pemecahan masalah (Rostika dan Junita, 2017).

Berdasarkan uraian di atas, peneliti menduga bahwa kemampuan siswa kelas $\mathrm{X}$ TKR 1 SMK Muhammadiyah 1 Pekanbaru dalam menyelesaikan permasalahan dalam pembelajaran masih rendah, karena hanya sedikit siswa yang dapat menyelesaikan permasalahan yang berkaitan dengan materi yang dipelajari saat itu. Untuk itu, peneliti melakukan tes Kemampuan Pemecahan Masalah Matematis (KPMM) pada materi Sistem Persamaan Linear Tiga Variabel yang bertujuan untuk mengukur sejauh mana Kemampuan Pemecahan Masalah Matematis siswa kelas X TKR 1 SMK Muhammadiyah 1 Pekanbaru yang berjumlah 31 orang. Penyelesaian dari soal tes yang diberikan merujuk pada tahap-tahap dalam proses pemecahan masalah matematis.

Tabel 1. Persentase Jumlah Siswa Kelas X TKR 1 SMK Muhammadiyah 1 Pekanbaru yang Memenuhi Indikator KPPM

\begin{tabular}{|c|c|c|}
\hline Indikator KPMM & $\begin{array}{c}\text { Jumlah Siswa } \\
\text { yang Memenuhi } \\
\text { Indikator } \\
\text { KPMM }\end{array}$ & $\begin{array}{c}\text { Persentase } \\
(\%)\end{array}$ \\
\hline Pemahaman masalah & 13 & 41,93 \\
\hline $\begin{array}{l}\text { Perencanaan } \\
\text { penyelesaian }\end{array}$ & 10 & 32.25 \\
\hline $\begin{array}{l}\text { Melaksanakan } \\
\text { perencanaan }\end{array}$ & 7 & 22,58 \\
\hline $\begin{array}{l}\text { Memeriksa kembali } \\
\text { proses dan hasil }\end{array}$ & 3 & 9,67 \\
\hline
\end{tabular}

Berdasarkan Tabel 1 dapat dilihat bahwa KPMM siswa masih rendah. Pada aspek pemahaman masalah, dari 31 siswa hanya 13 siswa yang menuliskan diketahui dan apa yang menjadi permasalahan dalam soal yang diberikan. Pada aspek perencanaan penyelesaian, hanya 10 dari 31 siswa yang dapat menuliskan ide penyelesaian masalah secara tepat dan selebihnya siswa menuliskan strategi penyelesaian kurang tepat. Hal ini menunjukkan bahwa siswa kurang mampu dalam merencanakan penyelesaian dalam pemecahan masalah. Pada aspek melaksanakan perencanaan penyelesaian, yaitu menyelesaikan soal dengan benar, lengkap dan sistematis terdapat 7 siswa yang dapat menyelesaikan soal dengan benar. Pada aspek memeriksa kembali hasil dan proses, hanya 3 dari 31 siswa yang menafsirkan solusi dari permasalahan yang diberikan. Kegagalan siswa dalam menyelesaikan permasalahan yang diberikan guru merupakan indikasi bahwa rendahnya kemampuan pemecahan masalah matematis siswa (Kurniawati, dkk., 2014).

Berdasarkan uraian di atas, terlihat bahwa terdapat masalah dalam proses pembelajaran di kelas $X$ TKR 1 SMK Muhammadiyah 1 Pekanbaru. Permasalahan tersebut diantaranya, pembelajaran masih berlangsung satu arah, yaitu dari guru ke siswa sehingga siswa tidak aktif dalam proses pembelajaran. Kemudian, siswa kurang mampu dalam menyelesaikan soal dengan menggunakan langkah-langkah pemecahan masalah. Hal ini dikarenakan siswa terbiasa menyelesaikan soal rutin yang hanya menggunakan rumus dan mencontoh langkah pengerjaan soal yang dijelaskan sebelumnya oleh guru. Terlihat dari hasil tes KPMM siswa mengalami permasalahan pada materi Sistem Persamaan Linear Tiga Variabel, khususnya pada persoalan yang mengacu pada pemecahan masalah.

Untuk meningkatkan KPMM siswa kelas X TKR 1 SMK Muhammadiyah 1 Pekanbaru maka diperlukan suatu inovasi pembelajaran yang inovatif dan menarik sehingga mampu membiasakan siswa dalam menyelesaikan permasalahan yang berkaitan dengan KPMM. Salah satu model pembelajaran yang diharapkan dapat meningkatkan KPMM siswa adalah model 
Problem Based Learning (PBL). Peneliti menerapkan model PBL untuk memperbaiki proses pembelajaran dan meningkatkan KPMM siswa kelas X TKR 1 SMK Muhammadiyah 1 Pekanbaru pada materi pokok Aturan Sinus dan Cosinus pada semester genap 2018/2019.

\section{METODE}

Jenis penelitian yang dilakukan adalah Penelitian Tindakan Kelas (PTK). Penelitian ini terdiri dari dua siklus, masing-masing siklus terdiri dari tiga kali pertemuan dan satu kali ulangan harian. Menurut Arikunto (2017) setiap siklus penelitian tindakan terdiri dari empat tahap meliputi: (1) perencanaan; (2) pelaksanaan; (3) pengamatan; dan (4) refleksi. Pada siklus pertama dilakukan tindakan berupa penerapan model PBL, dan pada siklus kedua dilakukan tindakan berupa PBL dengan perbaikan yang merupakan refleksi dari siklus pertama.

Populasi pada penelitian ini adalah seluruh siswa kelas $X$ TKR 1 SMK Muhammadiyah 1 Pekanbaru. Subjek pada penelitian ini adalah siswa kelas $\mathrm{X}$ TKR 1 SMK Muhammadiyah 1 Pekanbaru sebanyak 31 orang dengan tingkat kemampuan heterogen dan dilaksanakan pada semester genap tahun pelajaran 2018/2019. Instrumen pengumpul data yang digunakan adalah lembar pengamatan aktivitas guru dan aktivitas siswa serta tes KPMM. Data KPMM diperoleh berdasarkan nilai tes evaluasi akhir. Penilaian tes evaluasi akhir dikembangkan berdasarkan indikator untuk mengukur KPMM yang dikemukakan oleh Polya (dalam Roebyanto dan Harmini, 2017).

Data yang diperoleh melalui pengamatan dan tes KPMM siswa kemudian dianalisis menggunakan teknik analisis deskriptif naratif dan analisis statistik deskriptif. Data yang diperoleh dari lembar pengamatan merupakan data kualitatif dan dianalisis dengan teknik analisis deskriptif naratif yang bertujuan menggambarkan data tentang aktivitas guru dan siswa selama proses pembelajaran dan memaparkannya dalam bentuk narasi. Data yang diperoleh dari tes KPMM siswa dianalisis dengan teknik analisis statistik deskriptif.

Kriteria keberhasilan tindakan pada penelitian ini adalah sebagai berikut:
1. Terjadinya
Perbaikan
Proses
Terjadinya
perbaikan
proses

pembelajaran jika aktivitas guru dan siswa sesuai dengan langkah-langkah PBL yang direncanakan dan permasalahan yang dialami guru dan siswa dalam pembelajaran tidak terjadi lagi.

2. Peningkatan Kemampuan Pemecahan Masalah Matematis Siswa

Pada penelitian ini, KPMM siswa dikatakan mengalami peningkatan apabila terjadi peningkatan skor KPMM siswa dari skor awal (sebelum tindakan) ke skor tes KPMM siklus I dan skor KPMM siklus II.

3. Peningkatan Kemampuan Pemecahan Masalah Matematis Secara Klasikal

Peningkatan KPMM secara klasikal dapat dilihat dari nilai rerata KPMM siswa pada tes awal, siklus I, dan siklus II. KPMM secara klasikal meningkat jika nilai rerata KPMM siswa pada siklus I lebih tinggi dibandingkan nilai rerata pada tes awal KPMM, dan jika nilai rerata KPMM siswa pada siklus II lebih tinggi dibandingkan nilai rerata pada siklus I

\section{HASIL DAN PEMBAHASAN}

Pada siklus I proses pembelajaran belum seluruhnya sesuai dengan perencanaan. Kekurangan-kekurangan tersebut di antaranya adalah siswa cenderung bekerja secara individu, peneliti tidak memberikan PR dan tes formatif pada pertemuan pertama, kurangnya pemahaman siswa terhadap langkah-langkah pengerjaan LAS, serta siswa kurang partisipatif dalam presentasi kelompok. Kekurangan- kekurangan tersebut menjadi bahan perbaikan bagi peneliti pada siklus II. Proses pembelajaran pada siklus II mengalami perbaikan dari proses pembelajaran pada siklus I seiring dengan rencana perbaikan yang dilakukan peneliti dan siswa pun sudah terbiasa mengikuti proses pembelajaran dengan penerapan model PBL.

Proses pembelajaran pada siklus II sudah sesuai dengan perencanaan. Pada setiap pertemuan, proses pembelajaran sudah menjadi lebih baik. Hal ini dapat dilihat pada kegiatan pendahuluan dimana siswa sudah tampak khusyuk dalam berdoa, siswa selalu 
menginformasikan kehadiran sesuai dengan yang sebenarnya, guru selalu menyampaikan tujuan pembelajaran, siswa sudah aktif dalam menjawab apersepsi dan merespon motivasi yang disampaikan guru terkait dengan materi yang akan dipelajari.

Pada kegiatan inti, siswa sudah mampu mengorientasi masalah dengan tepat, mengorganisasikan rencana penyelesaian masalah, mengumpulkan informasi dan menyelesaikan masalah dengan berdiskusi sesama anggota kelompok, dan menyiapkan laporan hasil diskusi kelompoknya. Pada saat presentasi, siswa dapat menjelaskan penyelesaian masalah dengan baik dengan suara yang lantang dan tidak terbata-bata. Keberanian siswa untuk memberi tanggapan terhadap presentasi temannya juga semakin baik, yang ditandai dengan bertambahnya jumlah siswa yang memberi komentar di setiap pertemuan.

Pada kegiatan inti, siswa sudah dapat menyampaikan kesimpulan dari materi yang dipelajari. Pelaksanaan tes formatif juga selalu terlaksana dengan baik.

Seiring membaiknya proses pembelajaran, memberikan dampak kepada hasil tes KPPM pada akhir siklus I. Tes KPMM merupakan bagian dari Ulangan Harian I yang khusus mengkaji kemampuan siswa pada aspek kompetensi keterampilan. Rerata skor siswa untuk setiap aspek KPMM dapat dilihat pada Tabel 2.

Tabel 2. Rerata Skor Siswa Kelas X TKR 1 SMK Muhammadiyah 1 Pekanbaru untuk Setiap Indikator KPMM pada Siklus 1

\begin{tabular}{lccc}
\hline \multicolumn{1}{c}{$\begin{array}{c}\text { Indikator } \\
\text { KPMM }\end{array}$} & $\begin{array}{c}\text { Soal } \\
\text { Nomor } \\
\mathbf{4}\end{array}$ & $\begin{array}{c}\text { Soal } \\
\text { Nomor }\end{array}$ & $\begin{array}{c}\text { Soal } \\
\text { Nomor } \\
\mathbf{5}\end{array}$ \\
\hline $\begin{array}{l}\text { Pemahaman } \\
\text { masalah }\end{array}$ & 91,40 & 73,12 & 89,25 \\
$\begin{array}{l}\text { Perencanaan } \\
\text { pemecahan }\end{array}$ & 82,25 & 50,00 & 88,70 \\
$\begin{array}{l}\text { Melaksanakan } \\
\text { perencanaan }\end{array}$ & 50,53 & 32,25 & 72,04 \\
$\begin{array}{l}\text { Memeriksa } \\
\text { kembali proses } \\
\text { dan hasil }\end{array}$ & 25,80 & 11,29 & 61,29 \\
\hline
\end{tabular}

Sumber : Olah data pribadi, 2019

Dari Tabel 2 diperoleh informasi bahwa siswa sudah mulai dapat menyelesaikan masalah berdasarkan tahapan-tahapan pemecahan masalah, meskipun masih ada beberapa siswa yang melewatkan langkah pemecahan masalah terutama pada indikator perencanaan pemecahan dan pemeriksaan kembali proses dan hasil. Berikut ini akan dipaparkan peningkatan skor KPMM siswa pada Siklus I berdasarkan indikator KPMM.

1) Kemampuan Pemahaman Masalah

Kemampuan siswa dalam memahami masalah matematis mengalami peningkatan dibandingkan sebelum dilaksanakan tindakan. Pada tes kemampuan awal, banyak siswa yang langsung menuliskan rumus dan mengerjakan permasalahan matematika. Beberapa di antaranya tidak memahami masalah yang sedang dikerjakan sehingga penyelesaian masalah belum tepat. Pada tahap pemahaman masalah, siswa diminta untuk mengidentifikasi unsur-unsur yang diketahui, ditanyakan, dan informasi lain yang diperlukan. Pada tes KPMM Siklus I, sebagian besar siswa hampir mencapai skor maksimum untuk indikator pemahaman masalah. Hal ini dikarenakan siswa dapat menuliskan apa yang diketahui dan ditanyakan dalam soal secara tepat. Dari ketiga soal yang diberikan, pada soal kelima hampir seluruh siswa menuliskan diketahui dan ditanya, akan tetapi siswa belum lengkap menuliskannya sehingga banyak yang tidak mencapai skor maksimum. Untuk memperbaiki kekurangan dalam memahami masalah pada Siklus II, peneliti perlu menambah latihan soal yang bervariasi, agar siswa terlatih dalam memahami dan merumuskan masalah matematika dengan tepat.

2) Kemampuan Perencanaan Penyelesaian

Kemampuan ini menuntut siswa dapat menyusun model matematika dan merepresentasikan masalah menjadi bentuk segitiga untuk memudahkan dalam menyelesaikan permasalahan. Pada tes kemampuan awal, masih banyak siswa yang belum mampu merencanakan penyelesaian masalah. Hal ini dikarenakan siswa belum dapat mengidentifikasi masalah sehingga tidak mengerti langkah apa yang harus dikerjakan. Berdasarkan hasil tes KPMM Siklus I, sebagian besar siswa sudah mulai menuliskan perencanaan penyelesaian dengan tepat. Beberapa siswa yang tidak menuliskan 
perencanaan penyelesaian dengan tepat dikarenakan siswa salah dalam mengidentifikasi masalah sehingga siswa kesulitan dalam merencanakan penyelesaian masalah yang diberikan.

Untuk memperbaiki kekurangan siswa dalam merencanakan penyelesaian masalah pada Siklus II, peneliti akan memperbanyak latihan soal dengan menggunakan berbagai strategi penyelesaian. Hal ini diharapkan mampu membuat siswa lebih mudah dan terbiasa dalam merancang langkah penyelesaian soal.

3) Kemampuan Melaksanakan Perencanaan

Indikator ini menuntut siswa mampu menyelesaikan masalah matematika sesuai dengan langkah yang telah direncanakan. Jika siswa mengalami kesalahan dalam merencanakan penyelesaian, maka hasil penyelesaian juga akan salah. Pada tes kemampuan awal, sebagian besar siswa dapat menyelesaikan masalah, namun hanya setengah ataupun sebagian besar jawaban saja yang benar. Hal ini dikarenakan siswa melewatkan langkah memahami masalah serta belum dapat merencanakan penyelesaian masalah dengan benar.

Sebagian besar siswa salah dalam melaksanakan perencanaan penyelesaian karena siswa salah dalam menentukan konsep mana yang tepat untuk menyelesaikan masalah matematika yang diberikan. Hal ini disebabkan siswa kurang tepat dalam merumuskan masalah. Untuk memperbaiki kekurangan tersebut, peneliti akan memberikan soal-soal latihan yang menekankan siswa agar lebih teliti dalam merumuskan masalah sehingga nantinya dapat menuliskan jawaban secara lengkap dan benar.

4) Kemampuan Memeriksa Proses dan Hasil

Pada tes kemampuan awal, dari dua soal yang diberikan hanya tiga siswa yang memperoleh skor maksimal untuk indikator ini. Siswa belum terbiasa memeriksa kembali proses dan hasil yang telah diperoleh. Berdasarkan hasil tes KPMM Siklus I, masih terdapat beberapa siswa yang tidak menuliskan kesimpulan di akhir penyelesaian soal. Siswa beranggapan hasil pekerjaannya sudah benar sehingga tidak perlu dilakukan pemeriksaan lagi. Untuk memperbaiki kekurangan ini, peneliti akan memberikan pengertian tentang pentingnya melihat kembali langkah penyelesaian dan meminta siswa melakukan pemeriksaan hasil pekerjaan, apakah kesesuaian langkah penyelesaian dengan masalah yang diminta maupun perhitungan yang telah dikerjakan.

Perbaikan yang telah direncanakan berdasarkan refleksi Siklus I, selanjutnya diimplementasikan pada Siklus II. Secara keseluruhan, KPMM siswa semakin meningkat dibandingkan pada siklus I ataupun tes kemampuan awal sebelum pemberian tindakan. Meskipun masih terdapat beberapa siswa yang melewatkan langkah memeriksa kembali proses dan hasil, namun skor yang diperoleh tetap meningkat dibandingkan siklus sebelumnya. Hasil Tes KPMM pada Siklus II (Ulangan Harian II) disajikan pada Tabel 3.

Tabel 3. Rerata Skor Siswa Kelas X TKR 1 SMK Muhammadiyah 1 Pekanbaru untuk Setiap Indikator KPMM pada Siklus II

\begin{tabular}{lccc}
\multicolumn{1}{c}{$\begin{array}{c}\text { Indikator } \\
\text { KPMM }\end{array}$} & \begin{tabular}{c} 
Soal \\
Nomor \\
\cline { 2 - 4 }
\end{tabular} & $\begin{array}{c}\text { Soal } \\
\text { Nomor }\end{array}$ & $\begin{array}{c}\text { Soal } \\
\text { Nomor } \\
\mathbf{6}\end{array}$ \\
\hline $\begin{array}{l}\text { Pemahaman } \\
\text { masalah }\end{array}$ & 88,92 & 83,87 & 98,92 \\
$\begin{array}{l}\text { Perencanaan } \\
\text { pemecahan }\end{array}$ & 93,54 & 67,74 & 98,38 \\
$\begin{array}{l}\text { Melaksanakan } \\
\text { perencanaan }\end{array}$ & 80,64 & 46,24 & 92,47 \\
$\begin{array}{l}\text { Memeriksa } \\
\text { kembali } \\
\text { proses dan } \\
\text { hasil }\end{array}$ & 62,90 & 25,81 & 87,09 \\
\hline
\end{tabular}

Sumber : Olah data pribadi, 2019

Dari Tabel 3 dapat dilihat bahwa siswa banyak melakukan kesalahan pada soal nomor 5. Siswa kurang tepat dalam merencanakan penyelesaian masalah sehingga mengakibatkan terjadinya kesalahan dalam melaksanakan penyelesaian.

Untuk melihat peningkatan KPMM siswa sebelum dan sesudah penerapan model PBL pada materi pokok Aturan Sinus dan Cosinus, peneliti melakukan analisis kualifikasi KPMM yang dapat dilihat pada Tabel 4 . 
Tabel 4. Peningkatan Frekuensi Siswa pada Setiap Kualifikasi KPMM

\begin{tabular}{ccccl}
\hline $\begin{array}{c}\text { Interval } \\
\text { Skor }\end{array}$ & TKA & TS I & TS II & $\begin{array}{c}\text { Kualifikasi } \\
\text { KPMM }\end{array}$ \\
\hline $85-100,00$ & 3 & 10 & 16 & Sangat Baik \\
$70-84,99$ & 4 & 5 & 10 & Baik \\
$55-69,99$ & 2 & 10 & 5 & Cukup \\
$40-54,99$ & 4 & 6 & 0 & Kurang \\
$0-39,99$ & 18 & 0 & 0 & $\begin{array}{l}\text { Sangat } \\
\text { Kurang }\end{array}$ \\
\hline
\end{tabular}

Sumber : Olah data pribadi

Data pada Tabel 4 menunjukkan bahwa KPMM siswa pada setiap kualifikasi memperoleh peningkatan. Pada Tes Kemampuan Awal (TKS), sebagian besar kualifikasi KPMM siswa tergolong sangat kurang. Namun pada Tes Siklus (TS) I terjadi peningkatan kualifikasi menjadi cukup serta memperoleh kualifikasi sangat baik pada Tes Siklus (TS) II. Bahkan hasil TS II menunjukkan tidak ada lagi siswa yang memiliki kualifikasi kurang dan sangat kurang.

Meningkatkan KPMM siswa tidak terlepas dari penerapan model PBL yang peneliti lakukan. Penerapan PBL telah memberikan kesempatan kepada siswa untuk aktif dalam proses pembelajaran di antaranya menanggapi motivasi dan apersepsi dan diskusi kelompok untuk menyelesaikan LAS. Siswa juga terlatih dalam menyelesaikan masalah, berani menyampaikan pendapat serta mengajukan pertanyaan kepada guru. Berdasarkan kriteria keberhasilan tindakan dapat dikatakan bahwa tindakan yang peneliti lakukan telah berhasil karena adanya perbaikan proses pembelajaran dengan menerapkan PBL di kelas X TKR 1 SMK Muhammadiyah 1 Pekanbaru.

Berdasarkan data yang diperoleh pada siklus I dan siklus II (setelah dilakukan tindakan), secara keseluruhan KPMM siswa mengalami peningkatan. Rata-rata tes KPMM siswa pada Tes Siklus II meningkat menjadi 85,67 dibanding dengan hasil Tes Siklus I yang berkisar 72,09 dan pada Tes Kemampuan Awal yang berkisar 41,45. Hal ini sejalan dengan tindakan yang peneliti lakukan. Pada Siklus I, peneliti telah mengenalkan kepada siswa mengenai pentingnya menyelesaikan suatu masalah dengan menggunakan langkah-langkah pemecahan masalah. Namun, hasil Tes Siklus I menunjukkan masih terdapat beberapa siswa yang melewatkan langkah pemecahan masalah. Pada siklus II, peneliti memperbaiki kekurangan-kekurangan yang terjadi pada siklus I sehingga tidak ada lagi siswa yang melewatkan langkah pemecahan masalah.

Kesalahan yang dilakukan siswa berdasarkan analisis ketercapaian indikator KPMM pada Tes Siklus I dan Tes Siklus II adalah siswa kurang tepat dalam merumuskan penyelesaian masalah sehingga siswa mengalami kesalahan dalam menyelesaikan masalah tersebut. Selain itu, siswa tidak melaksanakan semua langkah penyelesaian dalam pemecahan masalah. Pembelajaran selanjutnya sebaiknya dilakukan dengan menambah soal latihan berbentuk pemecahan masalah dalam proses pembelajaran.

Berdasarkan analisis aktivitas guru dan siswa serta analisis hasil KPMM siswa dapat disimpulkan bahwa hipotesis tindakan yang diajukan dapat diterima kebenarannya. Dengan demikian, penerapan model PBL dapat meningkatkan KPMM siswa kelas $\mathrm{X}$ TKR 1 SMK Muhammadiyah 1 Pekanbaru pada materi pokok Aturan Sinus dan Cosinus tahun pelajaran 2018/2019. Hal ini sejalan dengan penelitian yang dilakukan oleh Komariah (2011) dan Gunantara dkk. (2014) yang menyatakan bahwa penerapan model Pembelajaran Based Learning dapat meningkatkan KPMM siswa yang diterapkan pada pembelajaran Kurikulum 2013.

\section{SIMPULAN}

Berdasarkan hasil penelitian yang telah peneliti lakukan, dapat disimpulkan bahwa penerapan model PBL telah memperbaiki proses dan meningkatkan kemampuan pemecahan masalah matematis siswa kelas $\mathrm{X}$ TKR 1 SMK Muhammadiyah 1 Pekanbaru semester genap tahun pelajaran 2018/2019 pada materi pokok Aturan Sinus dan Cosinus.

\section{REKOMENDASI}

Berdasarkan hasil penelitian yang telah diperoleh, peneliti merekomendasikan bahwa penerapan model PBL dapat dijadikan salah 
satu alternatif model pembelajaran yang dapat diterapkan untuk meningkatkan kemampuan pemecahan masalah matematika siswa melalui permasalahan dalam kehidupan sehari-hari yang terdapat pada Lembar Aktivitas Siswa (LAS). Penggunaan media Powerpoint lebih disarankan agar siswa lebih tertarik selama pembelajaran. Peneliti/guru harus terus melatih siswa untuk membiasakan diri mengungkapkan pemahamannya serta menanamkan keberanian dalam memberikan respon serta melatih siswa untuk bertanggung jawab dengan tugas yang diberikan. Peneliti/guru harus mengondisikan kelas agar siswa dapat belajar lebih aktif dan efektif dengan cara memberikan arahan dan perhatian lebih kepada siswa yang tertinggal dalam memahami materi.

\section{DAFTAR PUSTAKA}

Arikunto, S., Suhardjono, dan Supardi. (2017). Penelitian Tindakan Kelas. Jakarta: Bumi Aksara.

Gunantara, Gd., Suarjana, Md., Riastini N.Pt. (2014). Penerapan Model Pembelajaran Problem Based Learning untuk Meningkatkan Kemampuan Pemecahan Masalah Matematika Siswa Kelas V. Jurnal Mimbar PGSD Universitas Pendidikan Ganesha, 2(1).

Kemendikbud. (2014). Salinan Lampiran Permendikbud No. 58 Tahun 2014 Tentang Kurikulum 2013 Sekolah Menengah Pertama/Madrasah Tsanawiyah. Jakarta: Kemendikbud.
Komariah, K. (2011). Penerapan Metode Pembelajaran Problem Solving Model Polya untuk Meningkatkan Kemampuan Memecahkan Masalah bagi Siswa Kelas IX J di SMPN 3 Cimahi. Prosiding Seminar Nasional Penelitian, Pendidikan, dan Penerapan MIPA, 181-188.

Kurniawati, A., Yuwono, I., dan Muksar, M. (2014). Diagnosis Kesulitan Siswa SMP dalam Pemecahan Masalah pada Materi Teorema Phytagoras serta Upaya Mengatasinya Menggunakan Scaffolding. Prosiding Seminar Nasional Matematika Peranan Matematika dalam Menumbuhkan Daya Saing dan Karakter Bangsa, $33-42$.

Roebyanto, G., dan Harmini, S. (2017). Pemecahan Masalah Matematika untuk PGSD. Bandung: PT Remaja Rosdakarya.

Rostika, D., dan Junita, H. (2017). Peningkatan Kemampuan Masalah Siswa SD dalam Pembelajaran Matematika dengan Model Diskursus Multy Representataion (DMR). Edu_Humaniora, 9(1), 35-46 